\title{
Use of Low-molecular-weight Dextran in Management of Foetal Distress in Labour
}

\author{
J. B. JONES, * CH.M., F.R.C.S.ED., M.R.C.O.G.
}

Brit. med. F., 1964, 2, 909-910

The successful use of dextran of low molecular weight (Rheomacrodex) in the treatment of peripheral ischaemia is now well reported in the literature (Bergentz et al., 1961a, 1961b ; Gelin, 1961 ; Gelin and Ingelman, 1961 ; Long et al., 1961 ; Ratliff, 1963 ; Powley, 1963 ; Leak and Kemball Price, 1964 ; Bienenstock and Harding, 1964). By increasing the blood supply to the affected part function can be restored or gangrene prevented.

The object of this study was to see if, by improving the blood supply to the placental site, foetal distress could be alleviated, at least for sufficient time to allow vaginal delivery.

\section{Method}

The study was confined to cases where there was no obvious mechanical cause for the foetal distress, such as placental separation. Elderly primigravidae and patients with a bad obstetrical history were excluded. Foetal distress was judged on alteration of the foetal heart only - a tachycardia of above $160 /$ min., a bradycardia below $120 / \mathrm{min}$., or irregularity. Only when these changes were persistent was the case suitable for study.

An intravenous infusion of $500 \mathrm{ml}$. of $10 \%$ Rheomacrodex in $5 \%$ dextrose was given over a period of approximately 90 minutes, the first $250 \mathrm{ml}$. taking 30 minutes to run in. The foetal heart rate was recorded every 10 minutes. The patients were sedated previously if necessary and any dehydration or ketosis was corrected first.

Fifty consecutive cases were studied. In 18 cases the pregnancy was prolonged beyond the 41 st week: toxaemia of pregnancy was present in four and dysmaturity in one; and one case had repeated small haemorrhages in the ante-partum period. In the remaining 26 cases there was no obvious cause for the foetal distress at the time it appeared.

\section{Results}

In 41 cases the foetal heart rate returned to normal, 37 cases within one hour of starting the treatment. In the other nine

* Senior Registrar, the Whittington Hospital, London. cases there was either no effect at all or the return to normal was for a very short time (see Tables I and II and Chart).

\begin{tabular}{|c|c|c|c|}
\hline Foetal Heart & $\begin{array}{l}\text { No. of } \\
\text { Cases }\end{array}$ & Successful & Failed \\
\hline 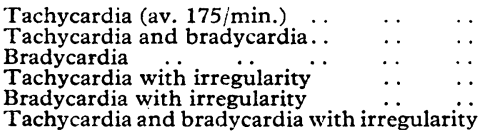 & $\begin{array}{r}29 \\
5 \\
1 \\
4 \\
9 \\
2\end{array}$ & $\begin{array}{r}22 \\
5 \\
0 \\
4 \\
8 \\
2\end{array}$ & $\begin{array}{l}7 \\
0 \\
1 \\
0 \\
1 \\
0\end{array}$ \\
\hline
\end{tabular}

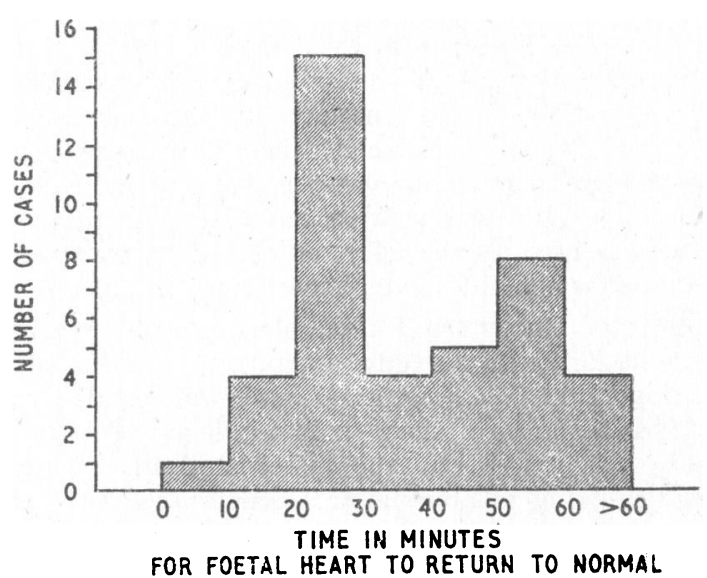

Of the 41 successful cases, 21 were delivered normally. Ten were delivered by forceps, five because of a return of foetal distress in the second stage, and five because of failure to advance. In 10 cases the cervix failed to dilate completely. One of these was delivered by the ventouse and nine by caesarean section. In three of these nine cases there was a return of foetal distress after four, five, and six hours of normality respectively.

There was one maternal death. After a prolonged and diffcult labour the patient was delivered by caesarean section because of failure to advance. Twenty-four hours postoperatively she sustained a fatal pulmonary embolus. Postmortem examination showed it to have come from thrombosis of the common iliac vein.

TABLE II.-Analysis of the Unsuccessful Cases

\begin{tabular}{|c|c|c|c|c|c|}
\hline Case No. & Foetal Heart & Foetal Heart after Rheomacrodex & Mode of Delivery & Reason for Distress & Outcome of Foetus \\
\hline 1 & $90 / \mathrm{min}$. irregular & \multirow{5}{*}{$\begin{array}{l}\text { Fell to } 80 / \mathrm{min} \text {. } \\
\text { No change } \\
\text { Fell to } 150 / \mathrm{min} \text {. after } 30 \text { mins., then rose steadily to } 200+/ \mathrm{min} \text {. } \\
\text { Fell to } 140 / \mathrm{min} \text {. in } 15 \mathrm{mins} \text {., stayed at this for one hour, then rose } \\
\text { to } 170 / \mathrm{min} \text {. } 45 \mathrm{mins} \text {. before delivery } \\
\text { Fell to } 160 / \mathrm{min} \text {. gradually in } 3 \text { hours, then to } 130 / \mathrm{min} \text {. in } 9 \text { hours. }\end{array}$} & \multirow{5}{*}{$\begin{array}{l}\text { Caesarean section } \\
\text { Normal } \\
\text { Caesarean section } \\
\text { Normal } \\
\text { Forceps }\end{array}$} & None found & \multirow{5}{*}{$\begin{array}{l}\text { Cried at birth } \\
\text { ", ", ", } \\
\text { Severe blue asphyxia. } \\
\text { Neonatal deaths } \\
\text { Cried at birth } \\
\text { Foetus not infected }\end{array}$} \\
\hline 3 & $\begin{array}{l}110 / \mathrm{min} . \\
170 / \mathrm{min}\end{array}$ & & & " & \\
\hline 4 & $170 / \mathrm{min}$ & & & $\begin{array}{l}\text { Premature" labour; } \\
\text { undiagnosed twins }\end{array}$ & \\
\hline 5 & $180 / \mathrm{min}$ & & & $\begin{array}{c}\text { Maternal pyrexia } \\
101 \cdot 2^{\circ} \mathrm{F} .\left(38 \cdot 4^{\circ} \mathrm{C} .\right)\end{array}$ & \\
\hline & & & & $\begin{array}{l}\text { Liquor infected } \\
\text { with } E \text {. coli }\end{array}$ & \\
\hline 6 & $176 / \mathrm{min}$. & Fell to $156 / \mathrm{min}$. in $30 \mathrm{mins}$, then rose rapidly to $180 / \mathrm{min}$. & Caesarean section & Cord tightly round & Severe blue asphyxia \\
\hline 7 & $160 / \mathrm{min}$ & \multirow{3}{*}{$\begin{array}{l}\text { Fell to } 140 / \mathrm{min} \text {. after } 45 \mathrm{mins} \text {., but rose quickly to } 166 / \mathrm{min} \text {. and } \\
\text { stayed there } \\
\text { No change } \\
\text { " " " }\end{array}$} & & None found & $" \quad, \quad \quad "$ \\
\hline $\begin{array}{l}8 \\
9\end{array}$ & 180/min. & & D-pos & "' "' & Cried at birth \\
\hline & & & Breech extraction & $\begin{array}{l}\text { Cord around foetal } \\
\text { neck }\end{array}$ & . $\quad, \quad, \quad$, \\
\hline
\end{tabular}


Four neonatal deaths occurred. In one pregnancy undiagnosed twins were delivered weighing $3 \mathrm{lb} .3 \mathrm{oz}$. (1,445 g.) and 2 lb. 13 oz. $(1,275$ g.). They survived only a short time. In another the baby died of pneumonia 12 hours after delivery. The fourth breathed for a short time but died very soon after birth. Post-mortem examination showed evidence of longstanding haemolysis with generalized bile-staining, but no cause for this could be found. Of the remaining 47 babies, 29 cried at birth and 18 had blue asphyxia and required resuscitation.

All patients were given routine oxytocics. There were two post-partum haemorrhages, each of $40 \mathrm{oz}$. (1,140 ml.). Both were due to failure of the uterus to contract.

\section{Discussion}

Rheomacrodex is a dextran with an average molecular weight of 40,000 . It acts by decreasing the viscosity of blood, preventing intravascular sludging, and by this means the supply of blood through the small vessels is improved. Temporary expansion of plasma volume takes place, and it should be used carefully in patients with cardiac disease. Care should also be taken to prevent leakage from the vein, as this will cause local oedema; and use of the drug is contraindicated in thrombocytopenia, pulmonary oedema, and sepsis.

It has been shown in open heart surgery (Breckenridge and Walker, 1963) that if the amount of Rheomacrodex given exceeds $20 \mathrm{mg} . / \mathrm{kg}$. of body weight there is increased operative bleeding, though there is no evidence that any increase occurs in the amount of post-operative bleeding. In this series a small dose was used, as the effect of prolonged treatment cannot be studied when the foetus shows signs of distress.

The effect of Rheomacrodex on blood-clotting mechanisms shows no abnormality directly attributable to the substance (Breckenridge and Walker, 1963) and, unlike dextran, the substance has no effect on cross-matching blood (Powley, 1963). Our study was marred by the maternal death. Pulmonary embolism occurring 24 hours after caesarean section is unusual.
There is no reason to suppose this was brought on by the treatment. Had the Rheomacrodex been given earlier to this patient and in a bigger dose, it is possible that by preventing venous stasis thrombosis would not have occurred.

The success of Rheomacrodex in alleviating the distress in these 41 cases makes it useful to the practising obstetrician, though a much larger series will have to be completed before a full assessment of its value can be made.

\section{Summary}

An attempt to improve the blood supply to the placental site by the fairly rapid infusion of $10 \%$ Rheomacrodex in dextrose is described. Its use in 50 cases of foetal distress in labour resulted in alleviation of the distress in 41 cases, 37 within one hour of starting the infusion.

There was one maternal and four neonatal deaths, but all of these were unconnected with the treatment. Two post-partum haemorrhages occurred, both due to failure of the uterus to contract.

There are few contraindications to the treatment, and these are outlined. A further large series will have to be completed before the full value of the drug can be assessed.

I would like to thank Mr. J. M. Scott and Mr. R. G. Law for allowing me to study patients under their care, and Sister M. E. T Surridge and her staff for their most helpful co-operation.

\section{REFERENCES}

Bergentz, S. E., Gelin, L. E., Rudenstam, C. M., and Zederfeldt, B. (1961a). Buil Soc. int. Chir., 20, 623 Bienenstock, J., and Harding, E. L. T. (1964). Lancet, 1, 524 Breckenridge, I. M., and Walker, W. F. (1963). Ibid., 1, 1190. Gelin, L. E. (1961). Acta chir. scand., Suppl. 210, p. 1. - and Ingelman, B. (1961). Ibid., 122, 294.

Leak, D and Kemball Price, R. (1964). Lancet, $1,772$.

. W. (1961). Surgery, 50, 12 .

Powley, P. H. (1963). Lancet, 1, 1189

Ratliff, A. H. C. (1963). Ibid., 1, 1188

\title{
A New Effective Diuretic-Lasix
}

\author{
WILFRED STOKES, * M.D., M.R.C.P. ; L. C. A. NUNN, † PH.D.
}

Brit. med. F., 1964, 2, 910-914

One of the diuretics containing the metadisulphamoyl group in the benzene ring, 4-chloro- $N$-(2-furyl-methyl)-5-sulphamoyl anthranilic acid (Lasix), has been tried intensively on the Continent and in America under the name of Fursemide. Experience of this preparation over 22 months and with more than 80 patients is now reported, the trial substance in the United Kingdom having been known as Salu 058, now available commercially as Lasix (Fig. 1).

\section{Previous Studies}

Preliminary animal studies with Lasix showed very safe margins of tolerance, with a diuretic response superior to that

\footnotetext{
- From the Department of Medicine, Stoke Mandeville Hospital, Aylesbury.
rom the Department of Pathology, Stoke Mandeville Hospital, From the
Aylesbury.
}

obtained with hydrochlorothiazide. Concentrations can be determined fluorometrically down to a concentration of 0.01 $\mu \mathrm{g} . / \mathrm{ml}$., and to some extent Lasix appears in the urine of man unchanged. Labelled with ${ }^{55} \mathrm{~S}$ and given to rats, 25 to $30 \%$ of the radioactivity was eliminated through the kidneys and $60 \%$ through the faeces (Reports from Hoechst Laboratories at Symposium on Fursemide, 1963).

Suzuki, Klutsch, and Heidland ${ }^{3}$ in experiments on dogs showed an increase of sodium and potassium rejection in the<smiles>[R16]c1cc(S(N)(=O)=O)c(Cl)cc1NCc1ccco1</smiles><smiles>NOS(=O)(=O)c1cc2c(cc1Cl)NCNS2</smiles>

HYDROCHLOROTHIAZIDE

FIG. 1 